\title{
Re-Os dating of auriferous pyrite from the Zhenyuan super-large gold deposit in Ailaoshan gold belt, Yunnan Province, Southwestern China
}

\author{
SHI GuiYong ${ }^{1,3}$, SUN XiaoMing ${ }^{1,2,3^{*}}$, PAN WeiJian ${ }^{2}$, HU BeiMing ${ }^{2}$, QU WenJun ${ }^{4}$, \\ DU AnDao ${ }^{4} \&$ LI Chao ${ }^{4}$ \\ ${ }^{1}$ School of Marine Sciences, Sun Yat-sen University, Guangzhou 510275, China; \\ ${ }^{2}$ Department of Earth Sciences, Sun Yat-sen University, Guangzhou 510275, China; \\ ${ }^{3}$ Guangdong Provincial Key Laboratory of Marine Resources and Coastal Engineering, Guangzhou 510006, China; \\ ${ }^{4}$ National Research Center of Geoanalysis, Beijing 100037, China
}

Received February 9, 2012; accepted April 26, 2012; published online June 22, 2012

\begin{abstract}
Zhenyuan gold deposit is the largest super large gold deposit in the Ailaoshan gold belt, but its precise mineralization age is still lack. Re-Os isotopic age of the auriferous pyrite from the Zhenyuan gold deposit was determined by using a high-resolution inductively coupled plasma mass spectrometry (HR-ICP-MS). The pyrite samples were decomposed in carius tubes, Os was separated by distillation and Re was extracted by acetone, respectively. The results show that the Re-Os isochron age is $229 \pm 38 \mathrm{Ma}$ (MSWD=2.0, confidence level is $95 \%$ ), with an initial ${ }^{187} \mathrm{Os} /{ }^{188} \mathrm{Os}$ value of $0.68 \pm 0.24$ and a corresponding $\gamma \mathrm{Os}$ value of $442 \pm 91$. The Re/Os ratios of the pyrite vary from 40.8 to 100.5 . The data suggest that at least one important ore-forming event was occurred during Indosinian epoch, and the ore-forming materials probably derived from mixed sources of crustal and mantle, while the later dominated. The Ailaoshan composite orogen experienced complicated evolutional processes, including formation of Precambrian-Early Paleozoic basement, subduction and orogenesis of Late Paleozoic era, collisional orogenesis of Late Hercynian-Indosinain epoch, and extensional or striking orogenesis of Yanshainan-Cenozoic epoch. The polycycle tectonic evolution and magmatism in this area caused multi-stage and superposition metallization characteristics of the Zhenyuan gold deposit: the mineralization probably occur mainly during the Indosinian collisional orogeny, while the minor gold ores of altered granite-porphyry and altered lamprophyre may be formed in the late superposition metallization.
\end{abstract}

Re-Os dating, auriferous pyrite, ophiolite melange, Zhenyuan super large gold deposit, Ailaoshan gold belt

Citation: Shi G Y, Sun X M, Pan W J, et al. Re-Os dating of auriferous pyrite from the Zhenyuan super-large gold deposit in Ailaoshan gold belt, Yunnan Province, Southwestern China. Chin Sci Bull, 2012, 57: 4578-4586, doi: 10.1007/s11434-012-5275-z

Being located in southeastern margin of the Qinghai-Tibet Plateau, the Ailaoshan gold belt is one of the economically most significant gold production bases in China. Since the 1980s, Mojiang gold deposit (large scale), Zhenyuan (super large scale and was called as "Laowangzhai gold deposit" in the early literatures) gold deposit, Daping gold deposit (super large scale) and Chang' an gold deposit (large scale), and a series of small- to medium-sized gold deposits and miner-

*Corresponding author (email: eessxm@mail.sysu.edu.cn) alization points have been discovered. Among them, Zhenyuan gold ore field, located in the northern section of the Ailaoshan gold belt, is the most representative and the largest one. Recently, there is an important breakthrow of gold exploration in the gold ore field.

Since discovered in the 1985 s, the Zhenyuan gold deposit was extensively investigated by many researchers, including metallogenic and geological characteristics, ore-control factors, ore forming fluid, source of ore-forming materials, metallogenic epochs and genesis, but its precise metallo- 
genic age is still lack. As for the genesis of the gold deposit, many views were put forward by different scholars, including volcanic hydrothermal [1], lamprophyre alterated [2], hydrothermal alterated [3], ultramafic-mafic rocks altered [4], metamorphic hydrothermal [5], structure alterated [6], etc. However, the Re-Os isotopic dating and tracing research of the deposit has not been reported. In recent years, with the large-scale development of open pits and emerging, some new geological phenomenon, more and more evidences show that genesis of the Zhenyuan gold deposit is closely related to the ophiolite melange belt distributed in the region. In this study, Re-Os dating of the auriferous pyrite from Zhenyuan gold deposit was determined by HRICP-MS, in order to provide the isotopic evidences for the metallogenic age and the ore-forming material sources. Meanwhile, it is hopeful that the result may be helpful for gold exploration in the deep portion and peripheral areas.

\section{Outline of regional geology}

The Zhenyuan gold ore field is located in the Ailaoshan combined belt and intersections of Jiujia-Anding fault and $\mathrm{NW}$-striking faults. The ore bodies are mainly distributed in the intersections of the NW-striking brittle-ductile shear zones and the EW-striking brittle-ductile thrust shear zones. In the gold ore field, major ore bodies, including Langnitang, Donggualin, Laowangzhai, Daqiaoqing and Kudumu, are distributed from northwest to southeast (Figure 1). Due to the effect of the $\mathrm{NW}$-striking brittle-ductile multiple shearing, a series of rock blocks with different lithologies are distributed along NW direction, and making the major gold ore bodies also NW-striking. While the EW- striking thrust brittle-ductile shear zone makes the stratum, dykes and some ore bodies nearly EW-striking. Magmatic activity was quite strong and the rock-type and occurrence are complicated. Previous researches showed that genesis of the Zhenyuan gold deposit is closely related to the ophiolite melange belt in the region [7-12]. The Langnitang ore block occurs mainly in the ultramafic rocks or in the altered fracture zone. Donggualin ore block occurs in the Devonian altered slate, which is mixed with pieces of the ophiolite mélange. Laowangzhai ore block mainly occurs in the Lower Carboniferous altered slate and the ophiolite melange

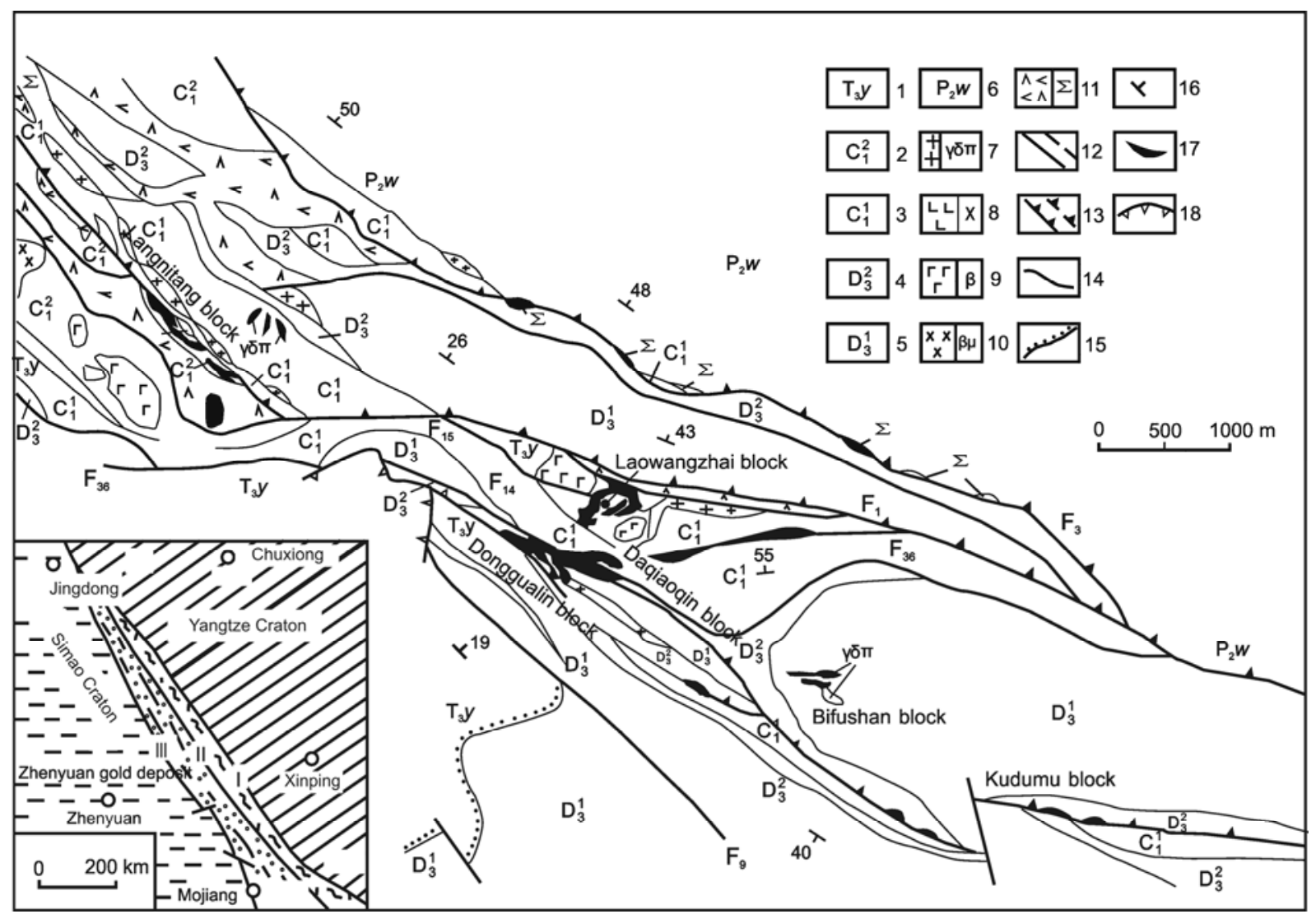

Figure 1 Geological sketch map of Zhenyuan gold ore field (modified after the unpublished research report of Geological Survey of Yunnan Province, 2008). 1, Siltstone of Upper Triassic Yiwanshui Fm.; 2, Lower Carboniferous slate; 3, Lower Carboniferous limestone; 4, Upper Devonian slate; 5, Upper Devonian metamorphic quartz wack; 6, schish of Paleozoic Waimaidi Fm.; 7, granodiorite porphyry; 8, lamprophyre; 9, altered basalt; 10, altered diabase; 11, altered ultrabasic rocks; 12 , measured and inferenced fault; 13, measured and inferenced shear zone; 14, geological boundary; 15, unconformable stratigraphic boundary; 16, strata occurrence; 17, gold ore bodies; 18, slumping accumulation boundary. I, Honghe fault belt; II, Ailaoshan fault belt; III, JiujiaMojiang fault. 
belt. The mineralization belt is about $8400 \mathrm{~m}$ long, and 100$500 \mathrm{~m}$ wide. The ore bodies are controlled by faults, and occur as group zones. The ore deposit is composed of 16 ore zones and 295 ore bodies, with 84 industrial ore bodies and 11 main ore bodies. The main ore bodies mostly occur in the strong deformational domains and as bedded or tabular textures. The occurrences of the gold ore bodies vary greatly along the ore-controlling faults, swelling, shrinking, branching, pinching, and reappearing occasionally. No clear boundaries between ore bodies and host rocks are recognized. The gold ore types are quite complicated, mainly including altered ultramafic rock type, alterated basalt type, altered metamorphic quartz greywacke type, alterated sericite slate type, altered granite porphyry and altered lamprophyre type, etc. Although a small number of quartz veins are weakly mineralized, does not constitute an ore type. The ore textures are mainly subhedral-granular texture, filling texture, interspersed and replaced texture. The structures including disseminated structure, thin veins structure and stockwork structures. In addition to native gold, the major metallic minerals are pyrite, arsenopyrite, stibnite, marcasite and copper sulfide. Non metallic minerals are mainly quartz, sericite and carbonates.

\section{Sampling and analytical procedure}

With a gold reserve of $66.26 \mathrm{t}$, the Donggualin is one of the largest ore bodies in the Zhenyuan gold ore field. The outcropped stratum in the ore body is an Upper Devonian $\left(\mathrm{D}_{3}^{1}\right)$ rock chip, its upper part consists of thin- to micro-layered metamorphic calcareous quartz greywacke, siliceous sericite sand slate, interlayered with micro-layered sandy and siliceous sericite slate, sandwiched occasionally with limestone lenses, and its lower part consists of the siliceous sericite green shale or siliceous chlorite sericite slate. The thickness of the Upper Devonian stratum is more than $200 \mathrm{~m}$. No clear boundaries between ores and hostrock can be recognized in the open pit. The boundary is determined by analysis of gold content. Besides, strong structure deformation in the ore field makes the sampling quite difficult. Five samples were collected. It is worth noting that the metamorphosed quartz graywack type gold ore is the predominant gold ore type in Langnitang, Laowangzhai and Donggualin ore bodies. In view of this, the samples in this study were collected at 62 exploration line of open pit in Donggualin ore body. The sampling position in geographical coordinates: longitude $23^{\circ} 53.954^{\prime} \mathrm{E}$, latitude $101^{\circ} 27.167^{\prime} \mathrm{N}$ (Figure 2). The sampled ores are auriferous pyrite-bearing metamorphosed quartz graywack. They are gray-colored, with massive to disseminated structure (Figure 3), and subhedral to euhedral granular and crushed granular textures (Figure 4).

Samples were handled by broken, water washing, magnetic selection, alcohol and heavy liquid separation, and finally the auriferous pyrites were hand picked under a

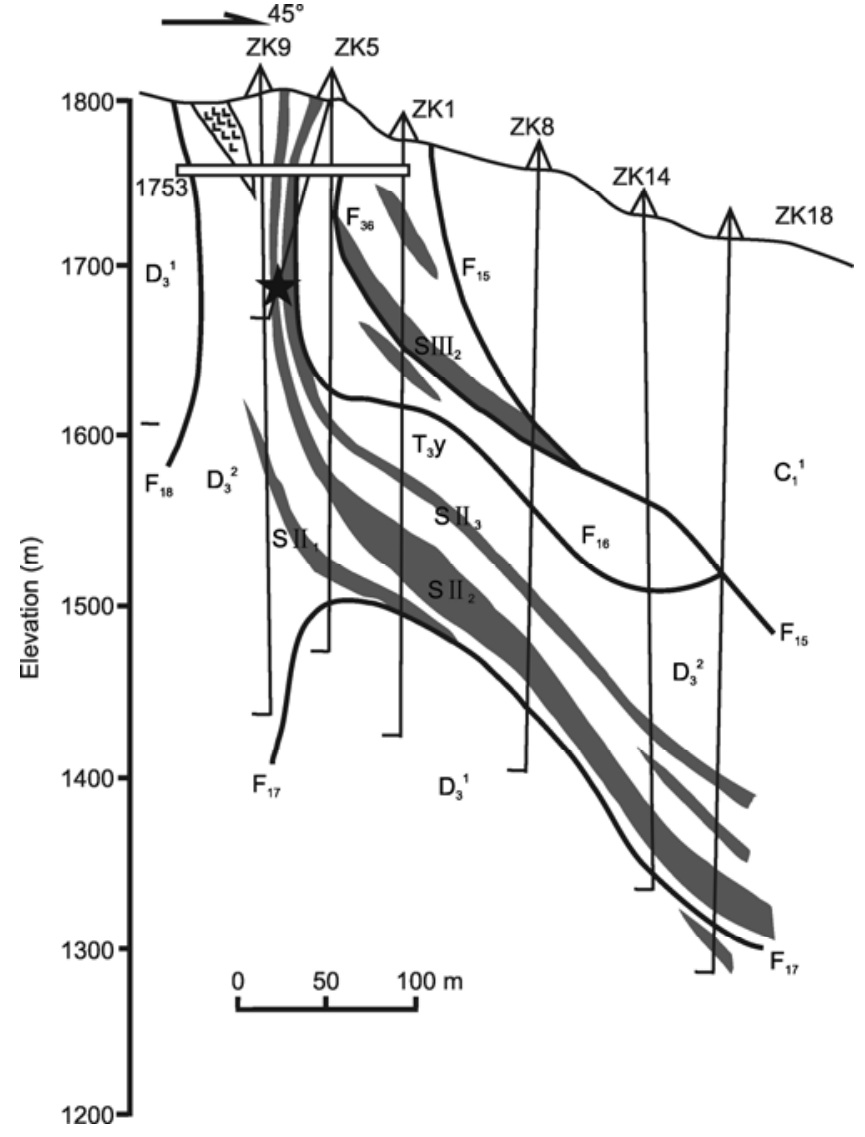

Figure 2 The profiles of No. 62 exploration line in Donggualin ore body. $\star$ Sampling position.

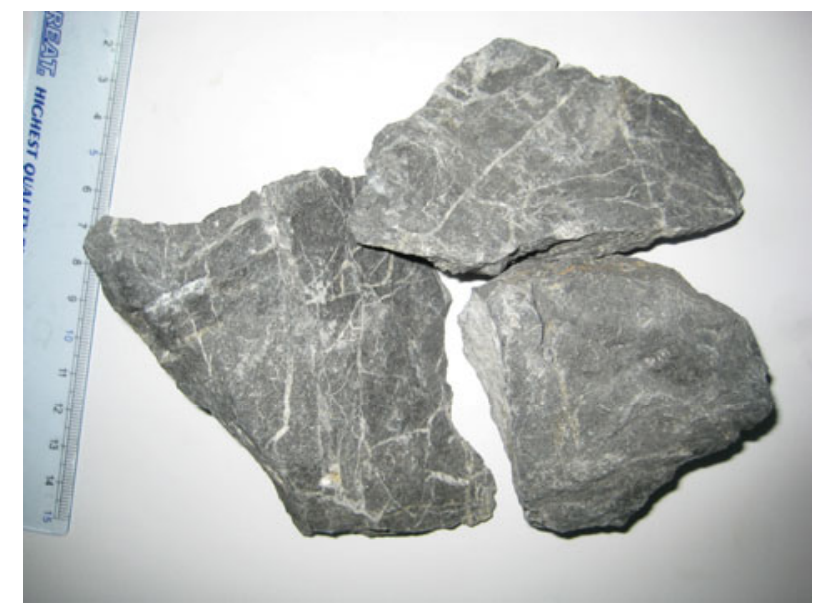

Figure 3 Metamorphosed quartz graywack type gold ore (sample number: DGL045).

binocular microscope. Each sample weights about $5 \mathrm{~g}$.

To check the purity of the selected samples, the samples were examined by using X-ray powder diffraction analysis at the Mineral Resources Institute of the Chinese Academy of Geological Sciences (CAGS). The results are shown in Table 1 and Figure 5. The X-ray diffraction diagrams showed 


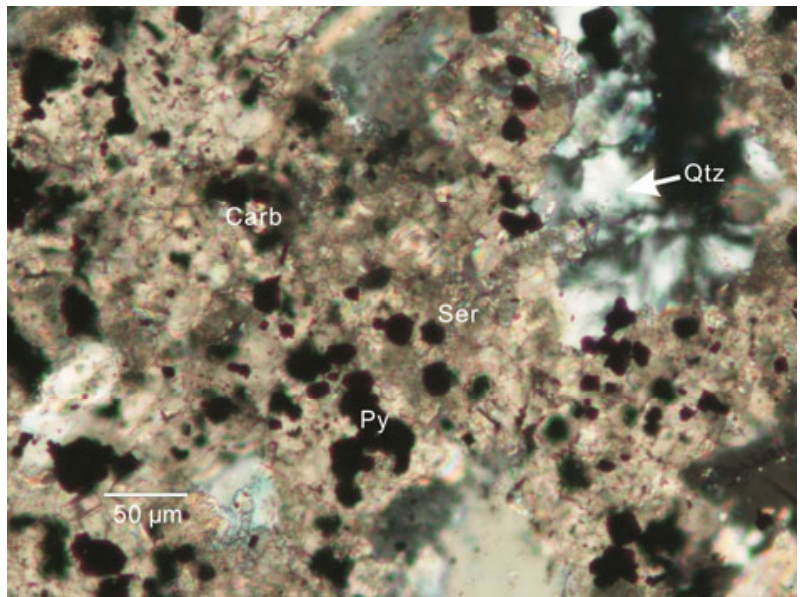

Figure 4 Micrograph picture of metamorphosed quartz graywack type gold ore under polarized light. Py, Pyrite; Qtz, quartz; Ser, sericite; Carb, caobonate.

Table 1 XRD date of pyrite from Zhenyuan gold ore field

\begin{tabular}{ccc}
\hline Sample & $a=b=c(\mathrm{~nm})$ & Crystal size $(\mathrm{nm})$ \\
\hline DGL-043 & 5.424 & 74 \\
DGL-044 & 5.4259 & 71.9 \\
DGL-045 & 5.418 & 137.3 \\
DGL-046 & 5.42 & 101.4 \\
\hline
\end{tabular}

that the selected pyrite samples do not contain other minerals, such as arsenopyrite.

Just as mentioned above, the metamorphosed quartz graywack type gold ore is the most important ore type in the Donggualin ore body, and pyrite is the most important auriferous mineral. However, no visible gold particles were found in the thin section under microscope. In order to determine gold occurrence in Zhenyuan gold ores, four pyrite samples for Re-Os isotopic analysis of were analyzed by atomic absorption spectrophotometer (AAS). The operating procedures: $100 \mathrm{mg}$ sample was weighed accurately and placed in $100 \mathrm{~mL}$ beaker, $10 \mathrm{~mL} 1.5 \%$ thiourea solution was added and soaked for $3 \mathrm{~d}$, during which, the beaker was treated by ultrasonic oscillations for three times, and $30 \mathrm{~min}$ per time. Then the filtrate collected in a test tube for the AAS analysis. Pyrite on the filter paper was washed by distilled water, and then put into the $100 \mathrm{~mL}$ beaker. The $10 \mathrm{~mL}$ fresh agua regia was added, the sample was resolved in the electric panel heating. The solution was heated and concentrated to wet salt-like at room temperature after the sample decomposition completely, and then was dissolved to $10 \mathrm{~mL}$ with Milli-Q water. The dissolved solution and thiourea solution were analyzed for Au content by AAS. Analytical results are presented in Table 2 . The results show that inclusion form gold is the major present form in the pyrites, while the fracture form gold is little in the pyrite, and thus the gold and the pyrite were formed nearly during the same metallogenic epoch. Therefore, Re-Os isotopic age of the auriferous pyrite may represent the main forming age of metamorphosed quartz graywack type gold ores.

Re-Os dating was performed at the Re-Os Laboratory in the National Research Center of Geoanalysis (NRCG), Chinese Academy of Geological Sciences (CAGS), Beijing. The Operating procedures is that the pyrite samples were decomposed in carius tubes, Os was separated by distillation, Re was extracted by acetone and further repurified by cation exchange column, Re and Os compositions and their isotopic ratios were determined by using a high-resolution inductively coupled plasma mass spectrometry (HR-ICPMS). The principle and details of the analytical methods were presented in references [13-15]. Selected isotopes for the measurement of Re were ${ }^{185} \operatorname{Re}$ and ${ }^{187} \mathrm{Re}$. sometimes a Re-bearing solution contained a small amount of incompletely separated ${ }^{187} \mathrm{Os}$, which would contribute to the ${ }^{187} \mathrm{Re}$ peak; accordingly, ${ }^{190}$ Os was selected as the monitor for ${ }^{187}$ Os. Selected isotopes for the measurement of Os were

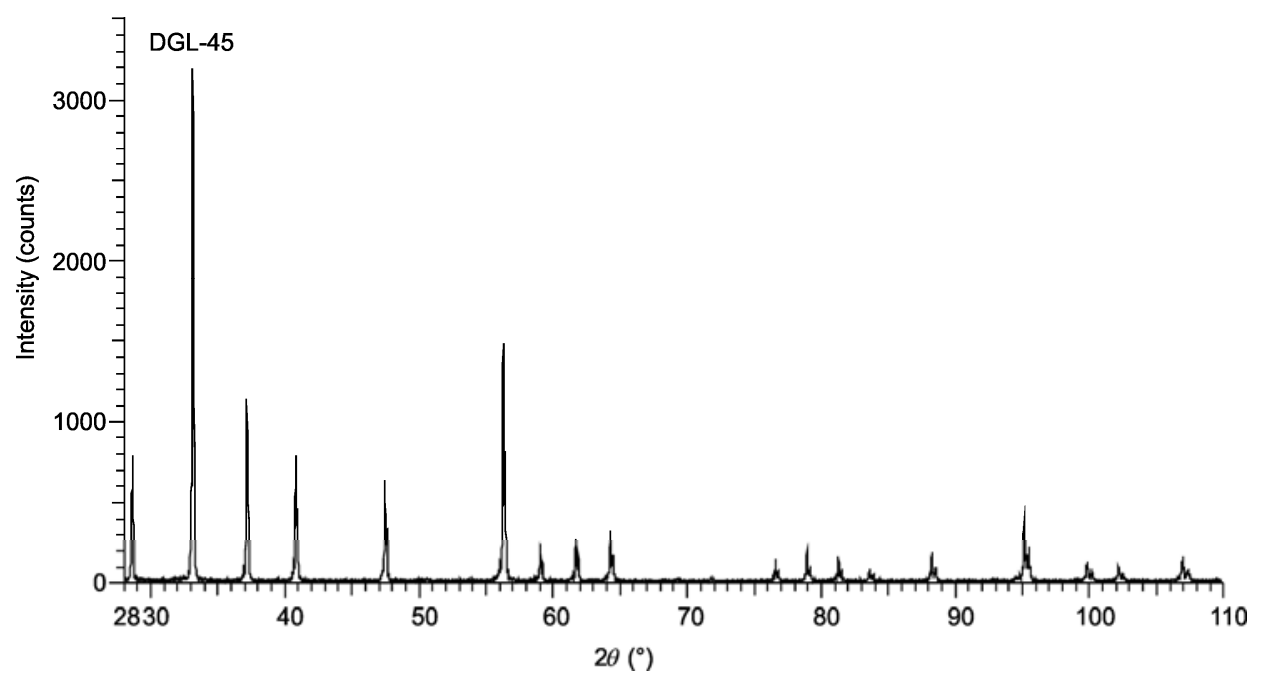

Figure 5 X-ray powder diffraction gram of pyrite from the Zhenyuan gold ore field. 
Table 2 Analytical results of the different gold occurrence in pyrite of Zhenyuan gold ore field

\begin{tabular}{lcccc}
\hline \multicolumn{1}{c}{ Sample } & DGL043 & DGL044 & DGL045 & DGL046 \\
\hline Weight $(\mathrm{mg})$ & 100 & 100 & 100 & 100 \\
Au content of the 1.5\% sulfourea soaking solution $(\mu \mathrm{g} / \mathrm{g})$ & 7.62 & 5.36 & 3.25 \\
Au content of aqua regia $(\mu \mathrm{g} / \mathrm{g})$ & 224.4 & 318.4 & 110.7 & 93.00 \\
\hline
\end{tabular}

${ }^{187}$ Os, ${ }^{190}$ Os and ${ }^{192}$ Os. Sometimes the $\mathrm{OsO}_{4}$ trap solution contained a small amount of unseparated ${ }^{187} \mathrm{Re}$, which would thus contribute to the ${ }^{187}$ Os peak; accordingly, ${ }^{185} \mathrm{Re}$ was selected as the monitor for ${ }^{187} \mathrm{Re}$. For the whole procedure, the blanks are less than $4 \mathrm{pg}$ for Re and less than $0.7 \mathrm{pg}$ for Os.

\section{Results}

Concentrations of $\mathrm{Re}$ and Os, and ${ }^{178} \mathrm{Re} /{ }^{188} \mathrm{Os}$ and ${ }^{187} \mathrm{Os} /$ ${ }^{188}$ Os isotopic ratios from the Zhenyuan gold deposit, corrected for total blanks, are list in Table 3. There is $1.02 \%$ uncertainty in the decay constant $1.666 \times 10^{-11} \mathrm{a}^{-1}$ for Re. The analytical data were processed by using ISOPLOT software, but measurement results show that only four samples to fit Re-Os isochron, one sample (DGL047) deviates significantly from the Re-Os isochron. The reason may be derived from operation errors, or the samples and other 4 samples are not belongs to the same veins. The obtained Re-Os isochron is presented in Figure 6.

Four pyrite samples from the Donggualin ore body yield a four-point isochron with an age of $229 \pm 38 \mathrm{Ma}(2 \sigma)$, an initial ${ }^{187} \mathrm{Os} /{ }^{188} \mathrm{Os}$ ratio of $0.68 \pm 0.24$, and a mean square of weighted deviation (MSWD) of 2.0, degree of confidence of $95 \%$, correspond to $\gamma \mathrm{Os}$ of $442 \pm 91$.

Standard sample (JCBY) and blank were used for quality control of analysis in the whole procedure. Contrasting measured values with the recommended values in Table 3, the dating is reliable and accurate.

\section{Discussion}

With the clean technology continues to improve and the new type of ICP-MS investment using, Re-Os isotope dating techniques have become increasingly mature and widely used for metal deposits dating [16-29]. Although the analysis precision for Re-Os isotopic ratios by HR-ICP-MS is not as good as that by N-TIMS, but the analysis results do not affect our discussion for the ore-forming age and source of the metallogenetic materials of Zhenyuan gold deposit.

\subsection{Mineralization age}

For study on genesis of any ore deposits, mineralization ages can provide vital information. There are three issues

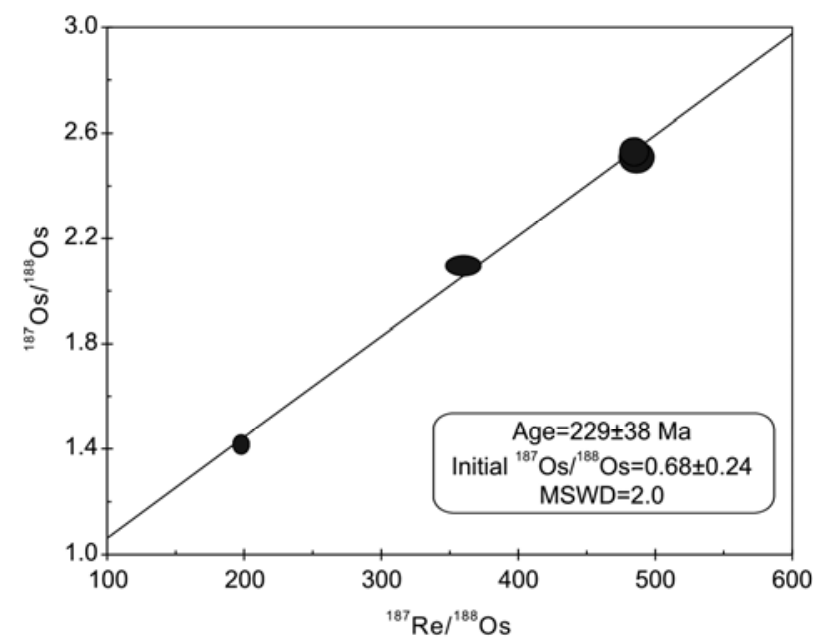

Figure 6 Re-Os isochron of pyrite from the Zhenyuan gold ore field.

must be pay attention at directly dating of gold mineralization: (1) whether the samples are gold ores or can represent gold mineralization; (2) whether the analytical samples were formed in the same metallogenic epoch of gold mineralization; (3) whether the testing method can accurately characterize the age of gold mineralization events [30]. Up to now, there are a lot of chronological data for Zhenyuan gold ore field, but all of them were obtained from indirect dating methods [31], and thus various shortcomings were existed [30-36]. For example, some previous researchers used $\mathrm{Rb}-\mathrm{Sr}, \mathrm{K}-\mathrm{Ar}$ and Ar-Ar dating ages of lamprophyre or its mica mineral to represent the forming age of gold deposit [30]. Electron Paramagnanetic Resonance (ESR) dating of quartz was also used to date the gold mineralization [18]. Besides, fission-track dating of apatite in the lamprophyre was also used to date the mineralization age [31]. In fact, previous studies shown that there is no direct genetic relationship between gold and the lamprophyre in the area $[37,38]$, thus, whether the formation age of Himalayan lamprophyre can represent different types of gold ore mineralization age is debatable. In the nearly developed open pit of Donggualin ore body, the gold reef was cut through by the quartz porphyry veins which dating 115.9 Ma [3].

The Re-Os isochron age of Zhenyuan gold deposit obtained in this study may get support evidences from previous $\mathrm{Pb}$ isotopes studies. The 51 samples (27 ore samples) from the different sections in Zhenyuan gold ore field were analyzed for $\mathrm{Pb}$ isotope by $\mathrm{Hu}$ et al. [1], and model ages of 200-270 Ma were obtained from the pyrite. Accordingly, 
Table 3 Re-Os isotope data of auriferous pyrite from Zhenyuan gold deposit

\begin{tabular}{|c|c|c|c|c|c|c|c|c|c|c|c|}
\hline \multirow{2}{*}{ Sample ${ }^{\text {a) }}$} & \multirow{2}{*}{$\begin{array}{l}\text { Weight } \\
\text { (g) }\end{array}$} & \multicolumn{2}{|c|}{$\operatorname{Re}(\mathrm{ng} / \mathrm{g})$} & \multicolumn{2}{|c|}{ Commonly Os (ng/g) } & \multicolumn{2}{|c|}{${ }^{187} \mathrm{Os}(\mathrm{ng} / \mathrm{g})$} & \multicolumn{2}{|c|}{${ }^{187} \mathrm{Re} /{ }^{188} \mathrm{Os}$} & \multicolumn{2}{|c|}{${ }^{187} \mathrm{Os} /{ }^{188} \mathrm{Os}$} \\
\hline & & Measured & Uncertainty & Measured & Uncertainty & Measured & Uncertainty & Measured & Uncertainty & Measured & Uncertainty \\
\hline DGL044 & 1.208 & 3.5665 & 0.0929 & 0.0479 & 0.0007 & 0.0131 & 0.0001 & 359.3 & 10.8 & 2.098 & 0.032 \\
\hline DGL043 & 1.222 & 1.0551 & 0.0118 & 0.0105 & 0.0002 & 0.0034 & 0.0000 & 485.9 & 10.6 & 2.510 & 0.049 \\
\hline DGL045 & 1.254 & 4.7436 & 0.0521 & 0.0473 & 0.0007 & 0.0156 & 0.0002 & 484.2 & 8.6 & 2.530 & 0.043 \\
\hline DGL046 & 1.230 & 0.8445 & 0.0111 & 0.0207 & 0.0004 & 0.0038 & 0.0000 & 196.9 & 4.8 & 1.420 & 0.030 \\
\hline DGL047 & 1.216 & 0.5975 & 0.0051 & 0.0079 & 0.0001 & 0.0017 & 0.0001 & 363.2 & 5.3 & 1.679 & 0.053 \\
\hline 8013 & 0.612 & 0.4589 & 0.0046 & 0.0181 & 0.0005 & 0.0043 & 0.0002 & 122.7 & 3.7 & 1.830 & 0.081 \\
\hline 8028 & 0.620 & 0.1623 & 0.0020 & 0.0044 & 0.0002 & 0.0006 & 0.0001 & 179.3 & 8.7 & 1.067 & 0.139 \\
\hline 8003 & 0.349 & 0.1436 & 0.0102 & 0.0140 & 0.0002 & 0.0028 & 0.0001 & 49.50 & 3.58 & 1.552 & 0.047 \\
\hline 8006 & 1.366 & 0.1211 & 0.0013 & 0.0296 & 0.0007 & 0.0035 & 0.0001 & 19.74 & 0.52 & 0.900 & 0.024 \\
\hline 8010 & 0.562 & 0.4430 & 0.0042 & 0.0139 & 0.0006 & 0.0033 & 0.0001 & 153.9 & 6.4 & 1.833 & 0.099 \\
\hline 8011 & 1.009 & 0.2137 & 0.0027 & 0.0166 & 0.0002 & 0.0044 & 0.0001 & 62.04 & 1.12 & 2.019 & 0.051 \\
\hline 8013 & 1.210 & 0.3968 & 0.0052 & 0.0171 & 0.0002 & 0.0050 & 0.0000 & 112.1 & 1.9 & 2.256 & 0.023 \\
\hline BJL-1 & 0.624 & 0.1120 & 0.0044 & 0.0015 & 0.0001 & 0.0004 & 0.0000 & 350.2 & 28.7 & 1.872 & 0.151 \\
\hline BJL-6 & 0.633 & 0.1231 & 0.0022 & 0.0021 & 0.0002 & 0.0002 & 0.0000 & 277.5 & 23.3 & 0.782 & 0.086 \\
\hline 04113 & 0.613 & 0.0267 & 0.0010 & 0.0008 & 0.0001 & 0.0002 & 0.0000 & 162.9 & 30.1 & 1.532 & 0.310 \\
\hline 04115 & 0.645 & 0.0370 & 0.0020 & 0.0016 & 0.0003 & 0.0001 & 0.0000 & 113.4 & 20.6 & 0.612 & 0.131 \\
\hline BB012 & 0.638 & 0.0517 & 0.0024 & 0.0025 & 0.0003 & 0.0004 & 0.0000 & 99.3 & 11.2 & 1.249 & 0.138 \\
\hline BB025 & 0.684 & 0.4152 & 0.0054 & 0.0180 & 0.0008 & 0.0032 & 0.0002 & 111.2 & 5.2 & 1.354 & 0.099 \\
\hline JCBY & 0.056 & 38.3282 & 0.4031 & 15.6550 & 0.1241 & 0.6788 & 0.0063 & 11.83 & 0.16 & 0.333 & 0.002 \\
\hline Recommended & & 38.61 & 0.54 & $16.23^{*}$ & 0.17 & & & & & 0.3363 & 0.0029 \\
\hline BK & & 0.0042 & 0.0027 & 0.0007 & 0.0000 & 0.0000 & 0.0000 & 29.97 & 19.29 & 0.267 & 0.140 \\
\hline BK & & 0.0030 & 0.0002 & 0.0004 & 0.0000 & 0.0001 & 0.0000 & 40.8 & 2.8 & 2.441 & 0.169 \\
\hline BK & & 0.0023 & 0.0001 & 0.0002 & 0.0000 & 0.0001 & 0.0000 & 50.29 & 5.04 & 2.339 & 0.328 \\
\hline
\end{tabular}

a) DGL043-DGL047 are samples of auriferous pyrite from the Donggualin ore body of Zhenyuan gold deposit; 8003-8013 are samples of pyrite from Chan'an gold deposit; 8028 is pyrite from syenite in Chan'an gold deposit; BJL1-BJL6 are auriferous pyrites from Bajiaolin ore body of Daping gold deposit; 04113-04115 are auriferous pyrites from eastern ore body of Daping gold deposit; BB012, BB025 are auriferous pyrites of Bangbu gold deposit in southern Tibet; JCBY was a monitor standard; BK, blank; * total content of Os.

a point of view for the Ailaoshan gold belt taking shape in the Late Hercynian-Indosinain was proposed. In addition, $\mathrm{Pb}$ isotopic model age of gold ores from the nearby Mojiang gold deposit is 114-304 Ma, with a peak value of $250 \mathrm{Ma}$ [39]. Chen et al. [40] also thought that there existed a close genetic relationship between Mojiang gold deposit and the ultrabasic rocks from ophiolite melange, and the magmatism and gold mineralization in the Mojiang area last a longer time, which caused multiphase and varying degrees gold mineralization from Hercynian to Himalayan epochs.

\subsection{Source of the metallogenetic materials}

The ${ }^{187} \mathrm{Os} /{ }^{188}$ Os initial value of $0.68 \pm 0.24$ was obtained from the Re-Os isochron in this work, which is significantly higher than the mantle's ${ }^{187} \mathrm{Os} /{ }^{188}$ Os ratio of 0.125 at $229 \mathrm{Ma}$, but is lower than the crust's ${ }^{187} \mathrm{Os} /{ }^{188} \mathrm{Os}$ ratio of 3.459 at $229 \mathrm{Ma}$, indicating that the source of the ore-forming materials in the Zhenyuan gold deposit was a crust-mantle mixing source. The conclusion can be clearly reflected in the evolution diagram of mantle, crust and ore's ${ }^{187} \mathrm{Os} /{ }^{188} \mathrm{Os}$ ratio vs. time (Figure 7). The initial evolutional time of the mantle is the Earth formation ages of $4.558 \mathrm{~Gy}$, and its initial ${ }^{187} \mathrm{Os} /{ }^{188} \mathrm{Os}$ ratio is 0.09531 . When the mantle evolved to 2.7 Gy before present, the crust was formed and its initial ${ }^{187} \mathrm{Os} /{ }^{188} \mathrm{Os}$ ratio is 0.0825 . With the individual evolution of the crust and the mantle, the crust's ${ }^{187} \mathrm{Os} /{ }^{188} \mathrm{Os}$ ratio was 3.459 at $229 \mathrm{Ma}$ (the mainly gold mineralization age), which was much higher than that of Zhenyuan gold mineralization at this time (0.68), while the mantle's ${ }^{187} \mathrm{Os} /{ }^{188} \mathrm{Os}$ ratio is 0.125 at the time, suggesting that at the early stage of gold mineralization, the ore-forming materials may come 


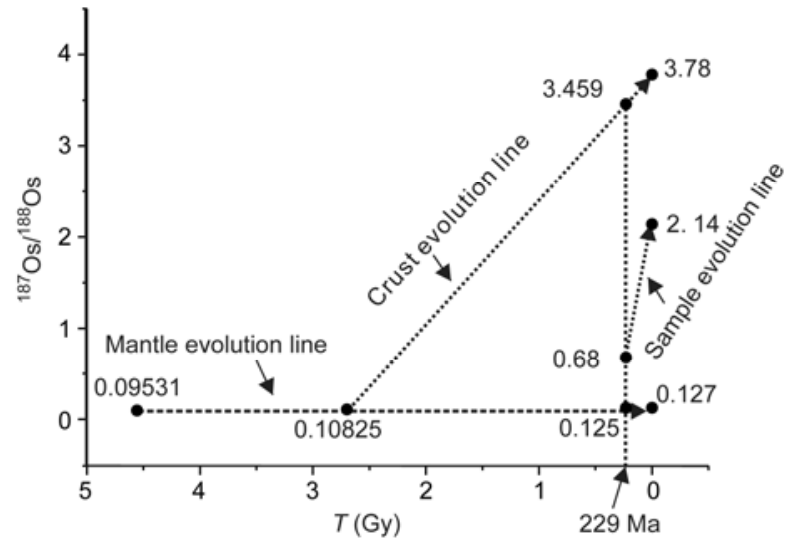

Figure $7{ }^{187} \mathrm{Os} /{ }^{188} \mathrm{Os}$ of mantle, crust and ores evolution with time.

from mixed crustal and mantle sources, but mainly from the mantle. Besides, the ${ }^{187} \mathrm{Os} /{ }^{188} \mathrm{Os}$ of the crust at present is about 3.78, and the mantle ${ }^{187} \mathrm{Os} /{ }^{188} \mathrm{Os}$ ratio is 0.127 , and the Zhenyuan gold deposit is 2.14 , indicating that there were crustal materials added during gold mineralization.

${ }^{187} \mathrm{Os} /{ }^{188} \mathrm{Os}$ initial value and $\gamma \mathrm{Os}$ of the primary upper mantle is 0.129 and +1.6 , while those of the average continental crust is 3.63 and +2758 [19]. The Maoling gold deposit in Liaoning Province, which possesses a typical character of crustal derivation of the ore-forming material, its ${ }^{187} \mathrm{Os} /{ }^{188}$ Os initial value was $1.23 \pm 0.48$ for auriferous arsenopyrite [20]. In contract, the ${ }^{187} \mathrm{Os} /{ }^{188}$ Os initial value and $\gamma$ Os are $0.68 \pm 0.24$ and $442 \pm 91$ for the Zhenyuan dold ore field, which is projected between the crust and mantle. Previous research work also shown that $\mathrm{Pb}$ isotopes of auriferous pyrites in the Zhenyuan gold deposit possessed mantle features $[1,6,34]$. Therefore, it is inferenced that the metallogenic materials in the Zhenyuan gold deposit may derive from mixed crustal and mantle sources, and mainly the mantle.

For Zhenyuan, Daping and Chan'an gold deposits, the auriferous pyrites are projected between the melt mantle and Lewisian lower crust in the common Os and Re/Os diagram (Figure 8), also suggesting that the ore-forming materials may come from mixed crustal and mantle sources, but mainly the mantle.

\subsection{The coupling of gold mineralization with tectonic and magmatic events}

Studies on tectonic and magmatic evolution of the Ailaoshan composite orogeny shown that it experienced a series of complex orogenic processes, such as Precambrian-Early Paleozoic basement formation, Late Paleozoic subduction and orogenesis, Late Hercynian-Indosinain collisional orogenesis, and Yanshainan-Cenozoic extensional orogenesis [42-44]. In the early of Carboniferous Period, the PaleoTethys Ocean was expansed, resulting in intensely seafloor spreading and mafic volcanic eruption, and formation of a rock suite of ophiolite mélange with high background content

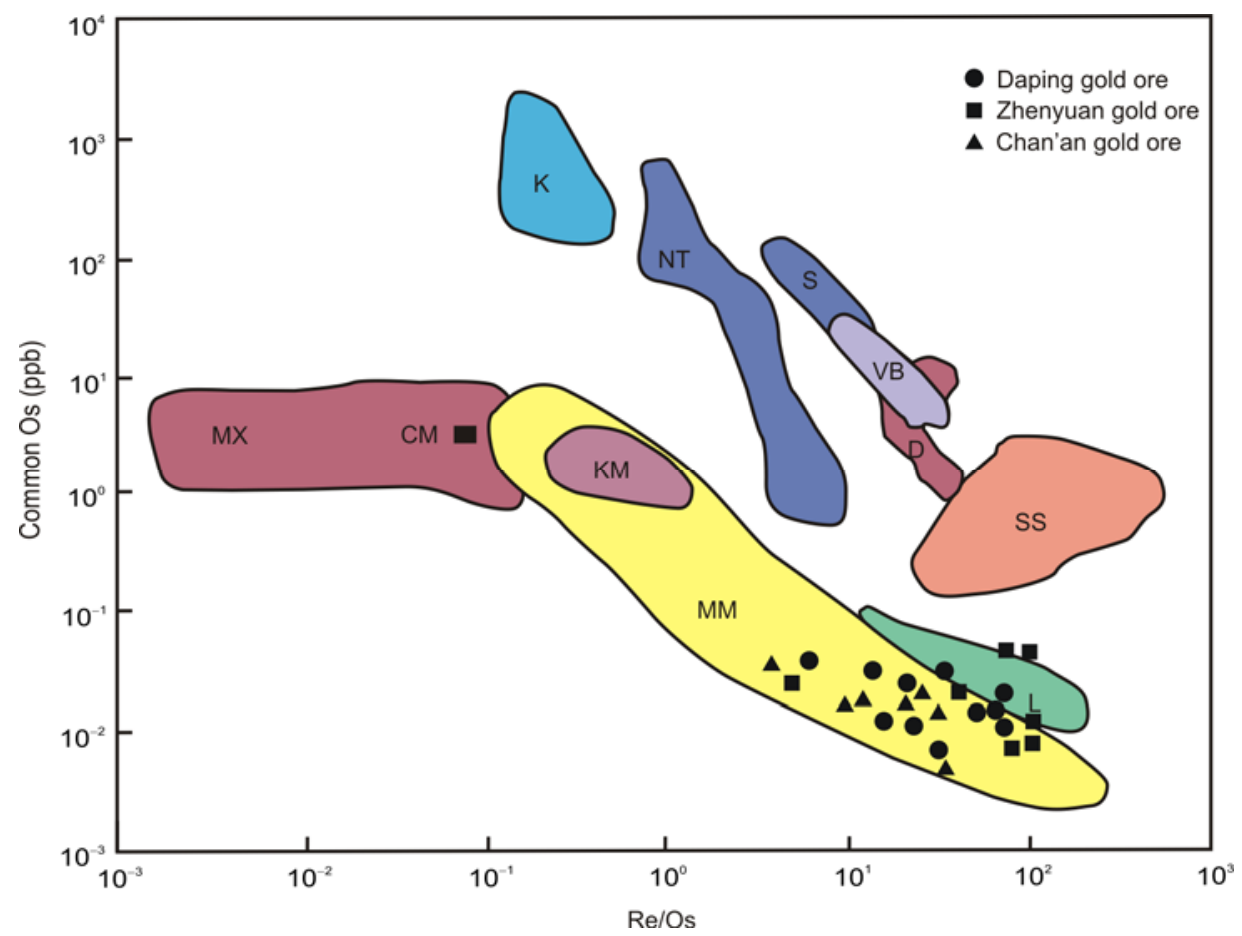

Figure 8 Re/Os vs. common Os diagram of auriferous pyrite from Ailaoshan gold belt (modified after Lambert et al. [41]). CM, Chondritic mantle abundances; D, Duluth sulphides; K, Kambalda sulphides; KM, Komatites; L, Lewisian Lower crust; MM, mantle melts; MX, mantle xenoliths; NT, Noril'sk-Talnakh sulphides; S, Sudbury sulphides; SS, S-rich sediments. 
of gold. The ophiolite melange consists of dunite-lherzolite, cumulate rocks, tholeiitic basalt, base dykes and chert, and its formation age was roughly $320 \mathrm{Ma}[45,46]$. A series of gold deposits, mineralization points and geochemical anomalies are basically distributed along with this melange in Ailaoshan gold belt [1]. Therefore, it is believed that the formation and evolution of the ophiolite melange belt was an important material basis for the Ailaoshan gold belt. The ophiolite of oceanic crust was subductetd from west to east in Early Late Permian Period, collided with the Yangtze block. Subsequently, Paleo-Tethys Ocean closed, corresponding to late Hercynian to Early Triassic colissional orogenesis. During the orogenesis, three deep faults (Red River, Ailaoshan and Jiujia-Mojiang) formed. In particular, the formation of Jiujia-Mojiang deep fault derived a series of nearly parallel secondary shear faults in its two sides. Formation of the different scale brittle-ductile shear zones played an important role in the generation, migration and precipitation of the ore-forming fluid [47]. During the intensive tectonic-magmatic activity, the gold was enriched and mineralized, which should be one of the most intensive gold mineralization in this area. Summary the history of tectonic and magmatic evolution of Ailaoshan gold belt and the predecessor's research results of the Zhenyuan gold ore field, we believe that the Zhenyuan gold ore field experienced several geological processes, the main mineralization period is the Indosinian, ore material source and mineralization fluid property with mantle source characteristics, the genetic type of ore deposit is the ophiolitic melange built type of gold mine. Altered granite porphyry type gold ore and altered lamprophyre type gold ore were formed due to later stage of reformed and superposited in Yanshan and Himalaya respectively.

\section{Conclusion}

(1) Re-Os isotope analysis of the metamorphosed quartz graywack type gold ore from the Zhenyuan gold deposit shown that its mineralization age is $229 \pm 38 \mathrm{Ma}$, suggesting that there existed at least an important ore-forming event during Indosinian epoch.

(2) The initial ${ }^{187} \mathrm{Os} /{ }^{188} \mathrm{Os}$ ratio, $\gamma \mathrm{Os}$ and ${ }^{187} \mathrm{Os} /{ }^{188} \mathrm{Os}$ ratio of the auriferous pyrite are $0.68 \pm 0.24,442 \pm 91$ and 1.420 2.530 respectively, which are higher than those of the mantle and lower than the crust. Connected with common Os vs. $\mathrm{w}(\mathrm{Re}) / \mathrm{w}(\mathrm{Os})$ ratios, it is proposed that the ore-forming materials may derive from mixed crustal and mantle sources, and mainly mantle.

(3) Genesis of the Zhenyuan gold deposit is closely related to the ophiolite melange belt, the time difference between intrusion of magmas and gold mineralization is about $100 \mathrm{Ma}$. The secondary ore types, including altered granite porphyry and lamprophyre-type gold ore, may be formed during later transformation and superposition.
This work was supported by the National Natural Science Foundation of China (40830425, 40673045 and 40373027), the National Basic Research Program of China (2009CB421006 and 2002CB412610), Research Fund for the Doctoral Program of Higher Education of China (200805580031) and the Project Supported by Guangdong Province Universities and Colleges Pearl River Scholar Funded Scheme (2011). We thank the engineers in Geological Section of Zhenyuan gold deposit for their kind support during our field work and sampling. The authors thank the two anonymous reviewers for their constructive comments and suggestions.

1 Hu Y Z, Tang S C, Wang H P, et al. Geology of Gold Deposits in Ailaoshan (in Chinese). Beijing: Geological Publishing House, 1995. 106-250

2 He W J. Characteristic of the lamprophyre and the relation with gold mineralization in Zhenyuan gold field (in Chinese). Yunnan Geol, 1993, 12: 148-158

3 Tang S C, Li J D, He S X. On metallogenic regularity of gold metallogenic belts in northern section of Ailao mountain (in Chinese). Yunnan Geol, 1991, 10: 44-70

4 Ren S L, Qin G J, Chi S C, et al. Au origin of LaowangzhaiDonggualin gold deposit, Zhenyuan County, Yunnan Province (in Chinese). Earth Sci, 1995, 20: 47-52

5 Shen S Y, Wei Q R, Cheng H L, et al. An approach to genetic types of the gold deposits in the Ailaoshan gold ore belt, Yunnan (in Chinese). Tethy Geol, 1997, 21: 73-84

6 Yang X H. A study on the genesis of Laowangzhai gold deposit of structural altered rock type in Zhenyuan County (in Chinese). Yunnan Geol, 2005, 24: 371-378

7 Tian N, Yang Y Q. Geology, geochemistry and genesis of gold deposits in ophiolitic melange in northern Ailao mountain, Yunnan (in Chinese). Contrib Geol Qinghai-Tibet Plat, 1991, 21: 84-97

8 Li D M, Li B H. The mineralization of the gold deposits in the Ailao mountain, Yunnan (in Chinese). Sediment Geol Tethy Geol, 2000, 20: 60-77

9 Bian Q T. Study of the relationship between crust-mantle structure and formation of Laowangzhai gold deposit (in Chinese). Sci China Ser D-Earth Sci, 1998, 28: 303-309

10 Yu G J. Types and ore-controlling conditions of primary gold deposits in the Ailaoshan gold ore belt (in Chinese). Geol Prosp, 1990, 26: 3-11

11 Ge L S, Deng J, Yang L Q, et al. Evolution of tectonic environment and gold-polymetal metallogenic system in Ailaoshan ore concentration region, Yunnan Province, China (in Chinese). Acta Petrol Sin, 2010, 26: 1699-1722

12 Ge L S, Deng J, Guo X D, et al. Deep-seated structure and metallogenic dynamics of the Ailaoshan polymetallic mineralization concentration area, Yunnan Province, China. Sci China Ser D-Earth Sci, 2009, 52: 1624-1640

13 Du A D, He H L, Yin W N, et al. A study on the Rhenium-Osmium geochronometry of molybdenites (in Chinese). Acta Geol Sin, 1994, 68: 339-347

14 Yang S H, Qu W J, Yang G, et al. The correction of mass fractionation in the measurement of Rhenium and Osmium isotope ration by ICP-MS (in Chinese). Rock Miner Anal, 2007, 26: 4-8

15 Li C, Qu W J, Du A D, et al. Comprehensive study on extraction of Rhenium with acetone in Re-Os isotopic dating (in Chinese). Rock Miner Anal, 2009, 28: 233-238

16 Zhao K D, Jiang S Y. Direct isotope dating for metallic ore deposits (in Chinese). Earth Sci Front, 2004, 11: 425-434

17 Du A D, Qu W J, Li C, et al. A review on the development of Re-Os isotopic dating methods and techniques (in Chinese). Rock Miner Anal, 2009, 28: 288-304

18 Jin X D, Li W J, Wu H Y, et al. Development of Re-Os isotopic dating analytical technique and determination know-how on ICP-MS precise dating for molybdenite (in Chinese). Acta Petrol Sin, 2010, 26: 1617-1624

19 Jiang S Y, Yang J H, Zhao K D, et al. Re-Os isotope tracer and dating methods in ore deposits research (in Chinese). J Nanjing Univ, 
2000, 36: 669-677

20 Yu G, Yang G, Chen J F, et al. Re-Os dating of auriferous arsenopyrite of the Maoling gold deposit, Liaoning Province, Northeast China and its geological significance. Chin Sci Bull, 2005, 50: 1509-1514

21 Feng C Y, Qu W J, Zhang D Q, et al. Re-Os dating of pyrite from the Tuolugou stratabound $\mathrm{Co}(\mathrm{Au})$ deposit, eastern Kunlun orogenic belt, northwestern China. Ore Geol Rev, 2009, 36: 213-220

22 Shi G Y, Sun X M, Wang S W, et al. Re-Os isotopic dating and its geological implication of Baimazhai $\mathrm{Cu}-\mathrm{Ni}$ sulphide deposit, Yunnan Province, China (in Chinese). Acta Petrol Sin, 2006, 22: 2451-2456

23 Chen M H, Mao J W, Qu W J, et al. Re-Os dating of arsenian pyrites from the Lannigou gold deposit, Zhenfeng, Guizhou Province, and its geological significances (in Chinese). Geol Rev, 2007, 53: 371-382

24 Liu Y L, Yang G, Chen J F, et al. Re-Os dating of the pyrite from Baiyunebo super REE-Nb-Fe deposit (in Chinese). Chin Sci Bull, 2004, 49: 2627-2631

25 Yang G, Chen J F, Du A D, et al. Re-Os dating of Mo-bearing black shale of the Laoyaling deposit, Tongling, Anhui Province, China. Chin Sci Bull, 2004, 49: 1396-1400

26 Wang D H, Qu W J, Li Z W, et al. The ore-forming centralism time of porphyry copper-molybdenum deposit in Jinsha River-Red River ore-forming belt: Re-Os isotope dating. Sci China Ser D-Earth Sci, 2005, 48: 192-198

27 Xie J C,Yang X Y, Du J G, et al. Re-Os precise dating of pyrite from the Xinqiao $\mathrm{Cu}-\mathrm{Au}-\mathrm{Fe}-\mathrm{S}$ deposit in Tongling, Anhui and its implications for mineralization (in Chinese). Chin J Geol, 2009, 44: 183-192

28 Selby D, Kelley K D, Hitzama M W, et al. Re-Os sulfide (bornite, chalcopyrite, and pyrite) systematics of the carbonate-hosted copper deposit at Ruby Creek, southern Brooks range, Alaska. Econ Geol, 2009, 104: 437-444

29 Stein H J, Morgan J W, Scherstén A. Re-Os dating of low-level highly radiogenic (LLHR) sulfides: The Harnasgold deposit, southwest Sweden, records continental-scale tectonic events. Econ Geol, 2000, 95: 1657-1671

30 Yang L Q, Deng J, Zhao K, et al. Tecono-thermochronology and gold mineralization events of orogenic gold deposits in Ailaoshan orogenic belt, southwest China: Geochronological constraints (in Chinese). Acta Petrol Sin, 2011, 27: 2519-2532

31 Yang L Q, Liu J T, Zhang Q, et al. Superimposed orogenesis and metallogenesis: An example from the orogenic gold deposits in Ailaoshan gold belt, Southwest China (in Chinese). Acta Petrol Sin, 2010, 26: 1723-1739

32 Bi X W, Hu R Z, He M Y. ESR dating and its geological implication of Ailaoshan gold ore belt (in Chinese). Chin Sci Bull (Chin Ver), 1996, 41: 1301-1303

33 Bi X W, Hu R Z, He M Y. The discussion about metallogenic age and metallogenic mechanism of the Ailaoshan gold ore belt (in Chinese). Geol Geochem, 1996, 24: 16-19

34 He M Y, Hu R Z. A study on genesis of the Laowangzhai gold deposit (in Chinese). Comput Tech Geophys Geochem Explor, 1996, 18: 17-20

35 Wang J H, Qi L, Yin A, et al. Emplacement age and PGE geochemistry of lamprophyres in the Laowangzhai gold deposit, Yunnan, SW China. Sci China Ser D-Earth Sci, 2001, 31(Suppl): 146-154

36 Wei J H, Liu C Q, Liu G C. Method of dating of gold deposit and the related problems (in Chinese). Earth Sci Front, 2003, 10: 319-326

37 Huang Z L, Liu C Q, Song C M, et al. Origin of the Lamprophyres and Their Relationship with Gold Ore in Laowangzhai Gold Deposit (in Chinese). Beijing: Geological Publishing House, 1999. 106-250

38 Zhu G T, Zhu S R. Discussion on lamprophyres and their relations to mineralization of gold deposits (in Chinese). Mineral Resour Geol, 1996, 10: 368-376

39 Zhang Z L, Zhang S F, Yuan $\mathrm{H} \mathrm{H}$, et al. An isotope geology and orogin study of the Jinchang gold deposit, Mojiang, Yunnan (in Chinese). J Chendu College Geol, 1987, 14: 29-41

40 Chen J R, Cui X B, Wu Y H, et al. Study on the diagenetic and metallogenic age of Jinchang gold deposit in Mojiang, Yunnan (in Chinese). Gold Geol, 2002, 8: 1-5

41 Lambert D D, Frick L R, Foster J G, et al. Re-Os isotope systematic of the Voisey's Bay Ni-Cu-Co magmatic sulfide system, Labrador, Canada: II. Implications for parental magma chemistry, oregenesis, and metal redistribution. Econ Geol, 2000, 5: 867-888

42 Zhang Z B, Liu F G, Bao J F. The structural evolution of Ailaoshan orogen (in Chinese). Yunnan Geol, 2005, 24: 137-141

43 Fan W M, Peng T P, Wang Y J. Triassic magmatism in the southern Lancangjiang zone, southwestern China and its constraints on the tectonic evolution of Paleo-Tethys (in Chinese). Earth Sci Front, 2009, 16: 291-301

44 Mo X X, Pan G T. From the Tethys to the formation of the QinhaiTibet Plateau: Constrained by tectono-magmatic events (in Chinese). Earth Sci Front, 2006, 13: 43-51

45 Jian $\mathrm{P}$, Wang $\mathrm{X} \mathrm{F}, \mathrm{He} \mathrm{L} \mathrm{Q}$, et al. U-Pb zircon dating of the Shuanggou ophiolite from Xinping County, Yunnan Province (in Chinese). Acta Petrol Sin, 1998, 4: 207-211

46 Jian P, Liu D Y, Sun X M. SHRIMP dating of Carboniferous Jinshajiang ophiolite, China: Geochronological constraints for the evolution of Paleo-Tethys oceanic floor (in Chinese). Acta Geol Sin, 2003, 77: 1-13

47 Liang Y H, Sun X M, Shi G Y, et al. Ore-forming fluid geochemistry and genesis of Laowangzhai large scale orogenic gold deposit in Ailaoshan gold belt, Yunnan province, China (in Chinese). Acta Petrol Sin, 2011, 27: 2533-2540

Open Access This article is distributed under the terms of the Creative Commons Attribution License which permits any use, distribution, and reproduction in any medium, provided the original author(s) and source are credited. 